\title{
Sensitive and Selective Spectrophotometric Assay of Lead in Aqueous Solution
}

\author{
Dheeya J. Yacoob \\ College of Agriculture \\ University of Salahaddin \\ Erbil - Iraq
}

(Received $17 / 3 / 2013$; Accepted 16/7/2013)

\begin{abstract}
A sensitive and selective spectrophotometric method for the determination of lead (II) in aqueous solution using zincon reagent has been developed. The pinkish red coloured complex was formed at $\mathrm{pH} 9.5$ which shows maximum absorption at $543 \mathrm{~nm}$. Beer's law is obeyed in the range $0.04-1.2 \mathrm{ppm}$ with a molar absorbtivity of $9.84 \times 10^{4} 1 . \mathrm{mol}^{-1} \mathrm{~cm}^{-1}$. The established stoichiometry is 1:1 ligand: metal. The method seems to be selective through the study of cationic and anionic interferences, easy, rapid, accurate, reproducible, and the complex is stable for 24 hours. The optimum conditions and the applications of the method have been studied for the assay of lead in different water samples.
\end{abstract}

Keywords: Lead determination, Zincon reagent, Aqueous solution, Masking agents, Spectrophotometry, Aanalytical applications.

\section{طرقة مسلسة و القائية لقحير الرصلهطيأفي المحلر المائي}

\section{|المالغص}

يتضمن هذا البهث طويرطريقةطيفية انقائية و مسلسة لقدير الرصاص (II) في المحلول المائي

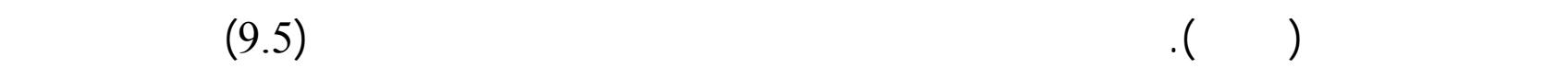

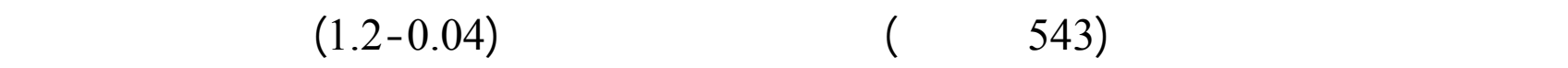

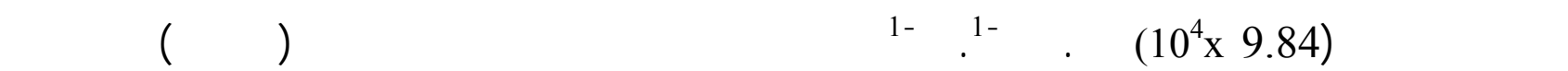

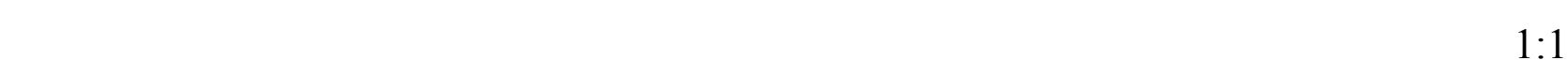

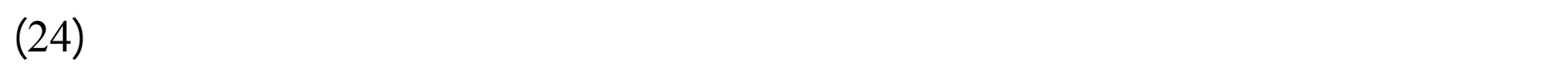
ساعة. إضافة إلى ذلك فلقد تمت درلسة جمبع الظروف المثلى التي تؤثر علىطبيعة المعقد المتكون، كما قم طبق الطريقة و بنجاح في ققدير الرصاص في نماذج مختلفة من الميه. 


\section{INTRODUCTION}

The determination of lead is very important from both the health and pollution points of view. Lead is the most important element which affects the physical properties of steel, alloys and high purity metals (Taher, 2003). A regular absorption of small quantities of lead may cause serious injuries to health such as encephalopathy and kidney, (Dos Santos et al., 2004). Lead poisoning is related to anemia, because the activity of heme synthetic enzymes can be inhibited by lead ions (Rubio, 2005). Lead is also a risk factor for hypertension in women (Houston and Johnson, 1999). $\mathrm{Pb}$ (II) determination in natural waters is of a considerable interest in the environmental sciences. (Nollet, 2000). In natural water, its typical concentration lies between 2-10 $\mu \mathrm{g} \mathrm{L}^{-1}$, whereas the upper limit recommended by WHO is less than $10 \mu \mathrm{g} \mathrm{L}^{-1}$ (Tewari and Singh, 2002). Concentrations of 5-10 $\mu \mathrm{g}$ lead in drinking water may increase urinary coproporphyrins (Wilson, 1966). The increased emphasis on trace lead determination developed a need for more rapid and accurate methods of analysis for this metal. Various methods are introduced to determine lead. Flame atomic absorption spectrometry (FAAS) is a more frequently used technique due to its simplicity and lower cost, although this method has a limited sensitivity for lead so a preconcentration step is often required to improve the detection limit (Vinas et al., 1997). Other detection techniques are also used such as inductively coupled plasma mass spectrometry (ICP-MS) (Hung et al., 1999). Spectrophotometric methods based on using the first order and second derivative for the determination of lead in synthetic alloy samples is developed (Nagalakshmi et al., 2011). 3,5-Dimethoxy-4-hydroxy benzaldehyde isonicotinyol hydrazone (DMHBIH) is used as an analytical reagent for lead determination. This reagent gives a bright yellow coloured water soluble complex in alkaline buffer solution at $\lambda=430$ $\mathrm{nm}$ and $\varepsilon=1.82 \times 10^{4}$. An on-line flow injection analysis system for the determination of lead in water samples with a preconcentration step and spectrophotometric detection was investigated (Klamtet et al., 2008). The system is based on the preconcentration of lead on a column packed with Amberlite XAD-4 resin. A new and selective method for the determination of trace amounts of lead in aqueous environmental samples was reported (Tan and Ngocle, 2010). The method is based on the interaction between $\mathrm{Pb}$ (II) and benzoic acid azophenyl calix (4) arene reagent. A simple and accurate flow injection analysis system coupled with spectrophotometric detection was developed (Klamtet et al., 2007) to the preconcentration and determination of lead in aqueous samples. This system is based on the reaction of $\mathrm{Pb}$ (II) with $\mathrm{PAR}$ at $\mathrm{pH} 9.0$ with absorption maximum at $\lambda=523 \mathrm{~nm}$. The determination of lead content in medicinal plants is developed by (Campos et al., 2009), using pre-concentration flow injection analysis flame A.A.S. This method exhibited a good performance with high precision and repeatability and an excellent linearity. A simple, economical, reliable and versatile method for lead was developed (Lang et al., 2009). The procedure has been validated by standard addition method and an ICP-MS method, it is based on the complex formation of lead with dithizone. A new flow injection on-line preconcentration system adapted to flame atomic absorption for lead and cadmium determination at the $\mu \mathrm{g} . l^{-1}$ was developed (Dadfarnia et al., 2007). The procedure was applied to tap water, river water, pine leaf and blood samples. A procedure for the determination of lead in water samples by solid phase spectrophotometry was developed (Pellerano et al., 2006). It is based on the reaction of $\mathrm{Pb}(\mathrm{II})$ ion with (5-Br-PADAP) reagent immobilized on an anion exchange resin that gives rise to a coloured complex, whose absorbance is measured directly in the solid phase. However, most of the used and applied 
methods to lead determination are based on spectrophotometry because of their simplicity, sensitivity, ease of handling and comparatively low cost as well as the high speed, precision and accuracy. During an investigation of a number of oraganic reagents selected as possible analytical reagents because of their structure, the reagent 2-carboxy -2- hydroxy -5 sulphoformazyl benzene (zincon), gives a highly coloured product with lead.

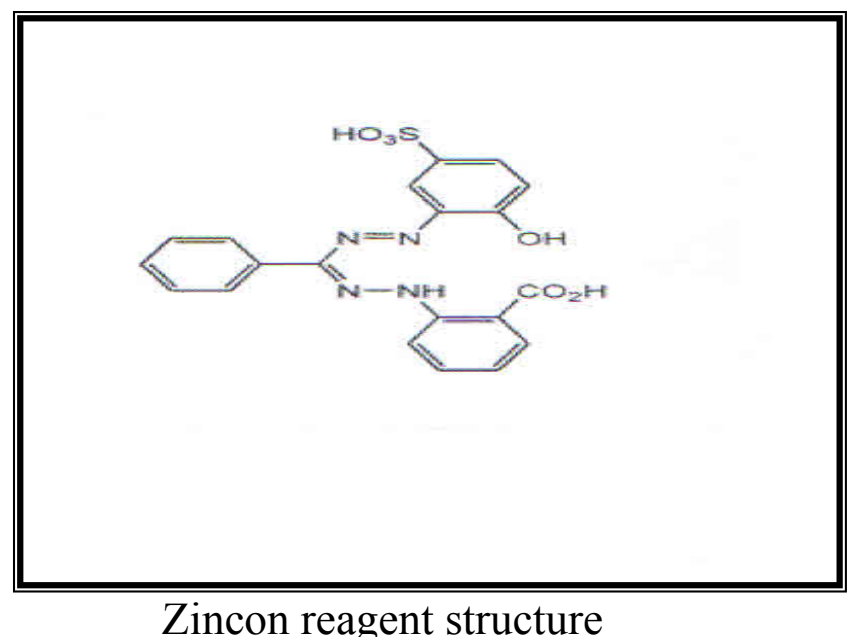

Zincon has been known as an excellent reagent for copper and zinc in aqueous solution (Sabel et al., 2010). Based on these findings, from the above literature survey of lead; this paper reports a spectrophotometric method using zincon reagent for a fast, sensitive and selective assay of lead traces in aqueous solution.

\section{Reagents}

\section{EXPERIMENT}

Unless otherwise stated, all chemicals used were of analytical reagent grade, and double distilled water was used all over the work.

\section{Stock lead (II) $(100 \mathrm{ppm}) \equiv \mathbf{4 . 8 2 6} \times 10^{-4} \mathrm{M}$ solution.}

This solution is prepared by dissolving $0.1598 \mathrm{~g}$ of lead nitrate $\left[\mathrm{Pb}\left(\mathrm{NO}_{3}\right)_{2}\right]$ (Fluka $\left.\mathrm{AG}\right)$ in double distilled water containing a few drops of $\mathrm{HNO}_{3}$. The volume is completed in 1000 $\mathrm{ml}$ volumetric flask, this solution is standardized against EDTA- $\mathrm{Na}_{2}$ solution using xylenol - orange as an indicator. (Vogel, 1961)

\section{Working lead (II) (10 ppm) solution.}

This solution is prepared by diluting $10 \mathrm{ml}$ of the above solution to $100 \mathrm{ml}$ with double distilled water, in a volumetric flask.

\section{Composite complexing solution; complexing solution No(l).}

This solution is prepared by dissolving $0.076 \mathrm{~g}$ of thiourea, $0.2542 \mathrm{~g}$ of 5sulphosalicylic acid, and $0.0419 \mathrm{gm}$ of sodium fluoride, in $80 \mathrm{ml}$ water, the $\mathrm{pH}$ of the solution is brought to 9.5 with $0.1 \mathrm{NaOH}$ and the volume is completed to $100 \mathrm{ml}$ with double distilled water in a volumetric flask.

Composite complexing solution No (II).

This solution was prepared daily by dissolving $0.1761 \mathrm{~g}$ of ascorbic acid in $80 \mathrm{ml}$ of water and the volume is completed to $100 \mathrm{ml}$ with double distilled water. 


\section{Zincon reagent $5 \times 10^{-4} \mathrm{M}$ solution.}

It is prepared by dissolving $0.0023 \mathrm{~g}$ of zincon powder in $2 \mathrm{ml}$ of $1 \mathrm{M}$ sodium hydroxide and diluting to $100 \mathrm{ml}$. This solution was stable for about one month, and it was stored in amber flask in the dark. Note that zincon is obtained from BDH(England) $\mathrm{C}_{20} \mathrm{H}_{15}$ $\mathrm{N}_{4} \mathrm{O}_{6}$ S.Na, Mwt =462.42, Product no. 13138.

\section{Buffer solution (pH 9.5).}

This solution is prepared by mixing $50 \mathrm{ml}$ of $(0.1 \mathrm{M}$ boric acid and $\mathrm{KCl})$ and $34.6 \mathrm{ml}$ of $\mathrm{NaOH}$, the volume is completed to $100 \mathrm{ml}$ with double distilled water. (Dempsey and Perrin, 1974).

\section{Apparatus}

Absorption spectra are recorded using shimadzu UV-160 UV-Visible computerized recording double -beam spectrophotometer. Absorbance reading is carried out on a Pye-Unicam SP-30 UV digital double-beam spectrophotometer, using 1-cm matched glass cells. $\mathrm{pH}$ readings (at $25 \mathrm{C}^{\circ}$ ) are made on $\mathrm{PW}-9421 \mathrm{pH}$ meter (Philip's), reading to \pm (0.001)pH unit.

\section{A.A.S Instrumental conditions}

Atomic absorption measurements are carried out using Shimadzu A.A 670 (Graphic printer).

Principle line $217.0 \mathrm{~nm}$

Flame: air - acetylene

Lamp current: Maximum 6 mA. Sensitivity: $0.035 \mathrm{mg} / 1$. Band pass:0.2 -0.5nm.

\section{Preliminary investigation}

\section{RESULTS AND DISCUSSION}

The visible spectra of the pinkish - red colour formed on mixing dilute $\mathrm{Pb}$ (II) solution and zincon reagent show an absorption band at $(535-545) \mathrm{nm}$ whereas the reagent blank shows maximum absorption at $476 \mathrm{~nm}$. This colour contrast $(\Delta \lambda \cong 69) \mathrm{nm}$, indicates a definite reaction in basic medium between $\mathrm{Pb}$ (II) and zincon reagent.

\section{Study of the optimum reaction conditions}

The effects of various parameters on the absorption intensity of the coloured complex are studied, and the reaction conditions have been optimized.

\section{Effect of pH}

The effect of $\mathrm{pH}$ on color intensity is first examined. Different volumes of $0.01 \mathrm{M}$ of $\mathrm{HNO}_{3}$ and $0.01 \mathrm{M} \mathrm{NaOH}$ solutions are added separately to an aliquot of solution containing $25 \mu \mathrm{g}$ of $\mathrm{Pb}$ (II) and $5 \mathrm{ml}$ of $5 \times 10^{-4} \mathrm{M}$ zincon reagent. The absorbances are read at $\lambda$ max of each solution and the $\mathrm{pH}$ of the final coloured solutions is measured. The results are shown in Table (1 and 2). From the results it can be observed that the $\mathrm{pH} 9.5$ is considered the optimum because of high sensitivity, low blank value. Higher $\mathrm{pH}$ values lead to higher blank and resulting in a weak colour contrast, while the absorbance decreases largely at low $\mathrm{pH}$ values. Therefore a $\mathrm{pH} 9.5$ is selected for the subsequent investigations. Different buffers of $\mathrm{pH} 9.5$ are prepared and their effects on the absorbance and the $\mathrm{pH}$ of the final reaction mixtures are studied. Five buffer solutions of $\mathrm{pH} 9.5$ have been tested. These are:boric acid- $\mathrm{NaOH}\left(\mathrm{B}_{1}\right)$, sodium borate- $\mathrm{NaOH}\left(\mathrm{B}_{2}\right)$, glycine- $\mathrm{NaOH}\left(\mathrm{B}_{3}\right)$, ammonia- 
ammonium chloride $\left(\mathrm{B}_{4}\right)$ and $\mathrm{Na}_{2} \mathrm{CO}_{3}-\mathrm{NaHCO}_{3}\left(\mathrm{~B}_{5}\right)$. The results are summarized in Table (3).

Table 1: Effect of $\mathrm{HNO}_{3}$ on absorbance

\begin{tabular}{|c|c|c|c|}
\hline $\begin{array}{c}\text { Ml of 0.01 M } \\
\mathrm{HNO}_{3}\end{array}$ & $\lambda_{\max }(\mathbf{n m})$ & Absorbance & Final pH \\
\hline 0.0 & 401 & 0.288 & 6.25 \\
\hline 0.1 & 405 & 0.221 & 5.87 \\
\hline 0.3 & 405 & 0.076 & 5.10 \\
\hline 0.5 & 406 & 0.007 & 4.22 \\
\hline 0.7 & 405 & 0.002 & 3.86 \\
\hline 1.0 & 401 & 0.005 & 3.65 \\
\hline
\end{tabular}

Table 2: Effect of $\mathrm{NaOH}$ on absorbance

\begin{tabular}{|c|c|c|c|}
\hline Ml of 0.01 M NaOH & $\boldsymbol{\lambda}_{\max }(\mathbf{n m})$ & Absorbance & Final $\mathbf{~} H$ \\
\hline 0.1 & 401 & 0.204 & 6.45 \\
\hline 0.3 & 468 & 0.242 & 7.15 \\
\hline 0.5 & 505 & 0.247 & 9.22 \\
\hline 0.6 & 520 & 0.310 & 9.29 \\
\hline 0.7 & 528 & 0.322 & 9.49 \\
\hline 0.9 & 530 & 0.337 & 9.53 \\
\hline 1.0 & 533 & 0.339 & 9.87 \\
\hline 1.5 & 537 & 0.411 & 10.23 \\
\hline 2.0 & 541 & 0.445 & 10.58 \\
\hline 2.5 & 542 & 0.476 & 10.67 \\
\hline 3.0 & 543 & 0.492 & 10.80 \\
\hline
\end{tabular}

Table 3: Effect of buffers on absorbance

\begin{tabular}{|c|c|c|c|c|c|}
\hline \multirow{2}{*}{$\begin{array}{c}\text { Ml of buffer } \\
\text { solution }\end{array}$} & \multicolumn{5}{|c|}{ Absorbance/ml of buffer added } \\
\cline { 2 - 6 } & $\mathbf{B}_{\mathbf{1}}$ & $\mathbf{B}_{\mathbf{2}}$ & $\mathbf{B}_{\mathbf{3}}$ & $\mathbf{B}_{\mathbf{4}}$ & $\mathbf{B}_{\mathbf{5}}$ \\
\hline 0.5 & 0.46 & 0.37 & 0.33 & 0.31 & 0.29 \\
\hline 1.0 & 0.47 & 0.38 & 0.35 & 0.33 & 0.30 \\
\hline 2.0 & 0.48 & 0.40 & 0.36 & 0.34 & 0.32 \\
\hline 3.0 & 0.48 & 0.42 & 0.39 & 0.34 & 0.33 \\
\hline 5.0 & 0.49 & 0.45 & 0.41 & 0.36 & 0.36 \\
\hline 7.0 & 0.51 & 0.59 & 0.43 & 0.37 & 0.35 \\
\hline$\lambda_{\max }(\mathrm{nm})$ & $540-543$ & $540-543$ & $540-543$ & $540-543$ & $540-543$ \\
\hline $\begin{array}{c}\text { Final pH of the } \\
\text { reaction mixture }\end{array}$ & $9.48-9.52$ & $9.10-9.34$ & $9.15-9.56$ & $9.15-9.37$ & $9.25-9.53$ \\
\hline
\end{tabular}

Although buffer solutions $\mathrm{B} 1, \mathrm{~B}_{2}, \mathrm{~B}_{3}, \mathrm{~B}_{4}$ give high sensitivity, $5 \mathrm{ml}$ of boric acid $\mathrm{NaOH}\left(\mathrm{B}_{1}\right)$ has been used for the subsequent experiments because of its relatively good capacity, lower blank value (0.076) and stronger colour contrast. 


\section{Effect of masking agents:}

In order to enhance the selectivity of zincon reagent as the case of some organic reagents which are reactive with a wide variety of metal ions, various masking agents were examined (Wilkinson, 1987). These are: sodium fluoride, oxalic acid, 5- sulphosalicylic acid, 1-10, phenanthroline, thiourea, ascorbic acid, citric acid, tartaric acid and hydroxyl amine hydrochloride. The results indicate that sodium fluoride, 5-(S.S.A), thiourea, and ascorbic acid have little effects on the absorbance of lead. Therefore, two solutions are prepared in which the first one contains $0.01 \mathrm{M}$ of each of sodium fluoride, 5-S.S.A and thiourea (ClS), and the second contains $0.01 \mathrm{M}$ of ascorbic acid (CIIS). The $\mathrm{pH}$ of the two solutions is adjusted to 9.5, and effect of different amounts of CIS in the presence of the same amounts of CIIS is tested. The results are shown in Table (4).

Table 4: Effect of composite complexing solution

\begin{tabular}{|l|l|l|l|}
\hline MI OF CIS & Absorbance & MI OF CIIS & Absorbance \\
\hline 0.5 & 0.385 & 0.5 & 0.388 \\
\hline 1.0 & 0.392 & 1.0 & 0.389 \\
\hline 2.0 & 0.480 & 2.0 & 0.485 \\
\hline 3.0 & 0.483 & 3.0 & 0.487 \\
\hline 4.0 & 0.484 & 4.0 & 0.487 \\
\hline 5.0 & 0.483 & 5.0 & 0.487 \\
\hline
\end{tabular}

$3 \mathrm{ml}$ of CIS and $4 \mathrm{ml}$ of the above complexing solutions were chosen in order to increase the selectivity.

\section{Effect of reagent amount:}

The effect of zincon reagent concentration on the maximum formation of the coloured complex was studied by using the described procedure and adding to a series of lead concentration $(1.0-10.0) \mathrm{ml}$ of zincon solution. The experimental data showed that $7 \mathrm{ml}$ of the used reagent seems to be optimum, because of a more stable absorbance reading of the complex is obtained here. The results are given in Table (5).

Table 5: Effect of reagent amount on complex formation

\begin{tabular}{|c|c|}
\hline Ml of reagent $\mathbf{5} \times \mathbf{1 0}^{-\mathbf{4}}$ solution & Absorbance \\
\hline 1 & 0.399 \\
\hline 2 & 0.445 \\
\hline 3 & 0.482 \\
\hline 4 & 0.484 \\
\hline 5 & 0.485 \\
\hline 7 & 0.487 \\
\hline 9 & 0.487 \\
\hline 10 & 0.486 \\
\hline
\end{tabular}




\section{Effect of surfactants:}

The effect of the presence of surfactants (cationic: $a=$ cetylpyridinium chloride, $b=$ cetyltrimethyl ammonium bromide, anionic: $\mathrm{c}=$ sodium dodecyl sulphate and $\mathrm{d}=$ gelatin as neutral) on the colour intensity of the complex are examined. The experiment reveals the presence of such compounds gives no useful effect.

\section{Effect of Time}

To define the suitable time for absorbance measurement, the effect of time on the development and stability of coloured complex is investigated under the optimum conditions. Complete colour formation occurs after $5 \mathrm{~min}$., and the absorbance of the complex remains constant for at least 6 hours.

\section{Order of the addition of reagents}

To test the effect of order of the addition of the reagents on the absorbance, solutions of order (I - IV) are tested as shown in Table (6). The experiment has shown that the order of addition NO.1: $(\mathrm{M}+\mathrm{CIS}+\mathrm{CIIS}+\mathrm{B}+\mathrm{R})$ gives the best absorbance in each of the all order of additions tested. $\mathrm{M}=\mathrm{Pb}^{+2}$ ion solution; CIS,CIIS (first and second complexing solutions); $\mathrm{B}=$ buffer solution; $\mathrm{R}=$ zincon reagent solution. Therefore, this order is selected for the subsequent experiments.

Table 6: Order of the addition of reagents

\begin{tabular}{|c|c|c|}
\hline Reaction components & Order number & Absorbance \\
\hline $\mathrm{M}+\mathrm{CIS}+\mathrm{CIIS}+\mathrm{B}+\mathrm{R}$ & I & 0.488 \\
\hline $\mathrm{M}+\mathrm{CIS}+\mathrm{CIIS}+\mathrm{R}+\mathrm{B}$ & II & 0.478 \\
\hline $\mathrm{M}+\mathrm{B}+\mathrm{CIS}+\mathrm{CIIS}+\mathrm{R}$ & III & 0.473 \\
\hline $\mathrm{M}+\mathrm{B}+\mathrm{R}+\mathrm{CIS}+\mathrm{CIIS}$ & IV & 0.470 \\
\hline
\end{tabular}

\section{Final absorption spectra}

When a buffered aqueous solution of lead (II) ions are mixed with zincon reagent at pH 9.5, a characteristic pinkish - red colour of binary complex is immediately formed (Fig. 1) shows the absorption spectra of the coloured complex with maximum intensity at $543 \mathrm{~nm}$ treated according to the recommended procedure, but no absorption obtained with the reagent at this wavelength (the reagent absorbs light at $\lambda=476 \mathrm{~nm}$ ). Therefore, all measurements were made at $543 \mathrm{~nm}$. 


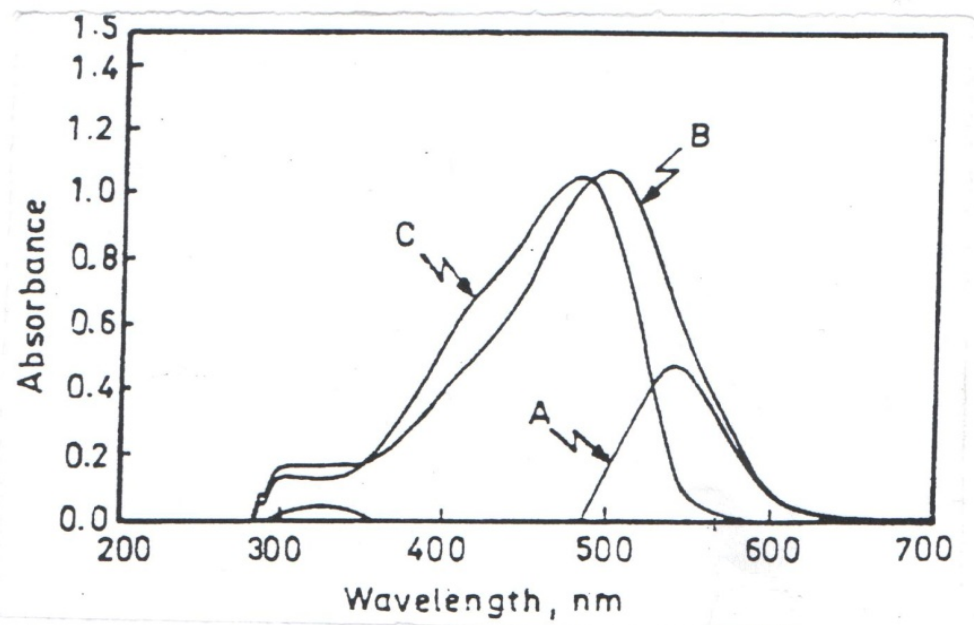

Fig. 1: Absorption spectra of $20 \mu \mathrm{gb}(\mathrm{II}) / 25 \mathrm{ml}$ measured, (A) against blank, (B) against distilled water and (C) blank against distilled water.

\section{Recommended Procedure and Calibration Graph}

To a series of $25 \mathrm{ml}$ volumetric flasks, increasing volumes of working $\mathrm{Pb}(\mathrm{II})$ solution are transferred to cover the range of 1.0-50 $\mu \mathrm{g} \mathrm{Pb}$ (II). $3 \mathrm{ml}$ of CIS and $4 \mathrm{ml}$ of CIIS solutions are introduced $5 \mathrm{ml}$ of buffer $\mathrm{pH} 9.5$ and $7.0 \mathrm{ml}$ of $5 \times 10^{-4} \mathrm{M}$ zincon reagent solution, are then added. The volumes are made to the mark with double distilled water. The reaction mixtures are mixed and absorbances are measured at $543 \mathrm{~nm}$, against a reagent blank prepared in the same manner but without lead. The absorbance remains constant for more than 24 hrs. A plot of absorbance versus determinand concentrations (Fig. 2) shows that Beer's law is obeyed over the range of (1.0-30.0) $\mu \mathrm{g}$ lead in a final volume of $25 \mathrm{ml}$, i.e, (0.04-1.2) ppm. The molar absorptivity being $9.84 \times 10^{4} 1 . \mathrm{mol}^{-1} . \mathrm{cm}^{-1}$, and a Sandell sensitivity index of $0.0021 \mu \mathrm{g} . \mathrm{cm}^{-2}$.

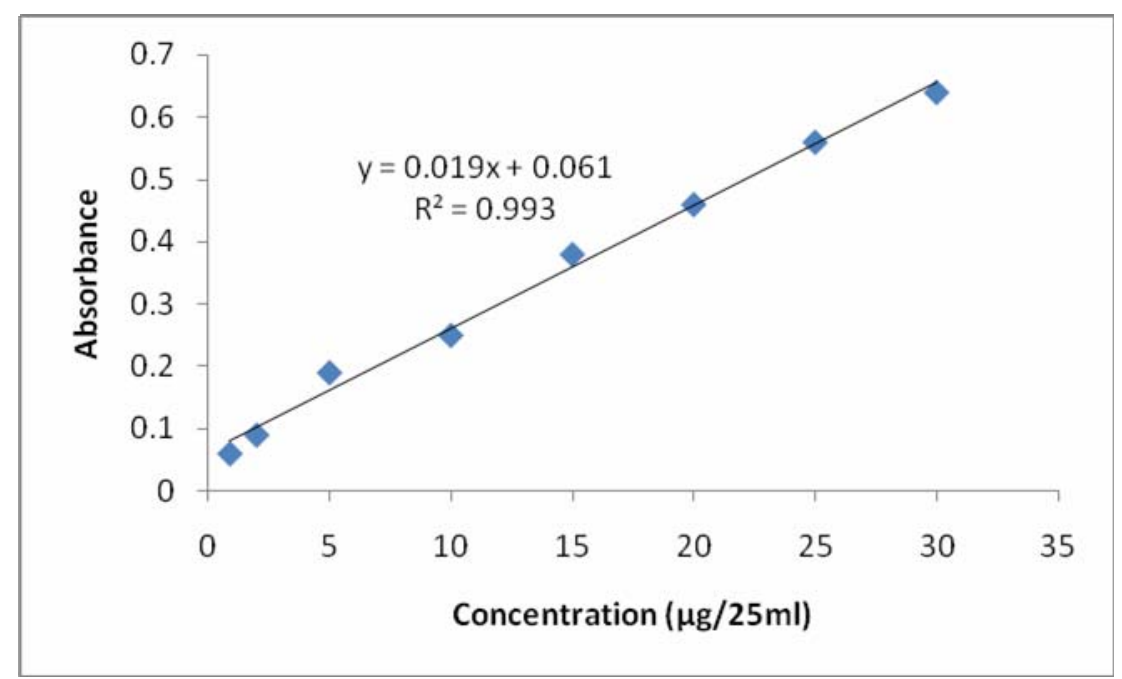

Fig. 2: Calibration graph for lead(II) determination with zincon reagent in aqueous solution 


\section{Accuracy and precision of the calibration graph}

Under the experimental conditions which included in the recommended procedure, the recovery and precision have been checked by performing five replicate determinations for $1.0,10,30 \mu \mathrm{g}$ of $\mathrm{Pb}(\mathrm{II})$, the recovery and relative standard deviation are 100.01,100.08, 99.75 and $^{ \pm} 4.44,{ }^{ \pm} 0.76,{ }^{ \pm} 0.47$ respectively, indicating a good accuracy and precision.

\section{Nature of the complex}

The nature of the complex was determined by Job's method of continuous variations and mole ratio method. (Hargis, 1988). The results reveal that the combination ratio of $\mathrm{Pb}$ (II): reagent is $1: 1$. Thus, the empirical formula of the coloured complex may be written as below.

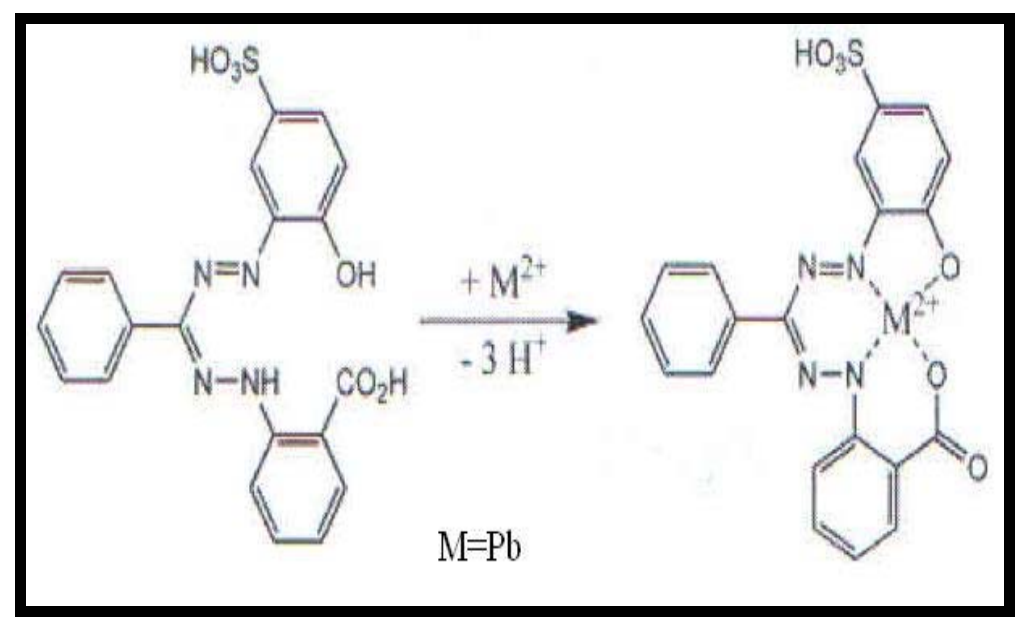

Fig. 3: Suggested structure of the complex

\section{Stability constant of the complex}

The conditional stability constant of the $1: 1 \mathrm{~Pb}(\mathrm{II})$ : reagent can be estimated using the following formula, (Hargis, 1988): $\mathrm{K}=\frac{1-a}{\alpha^{2} c}$. The mean value of $\mathrm{K}$ is found to be $2.27 \mathrm{x}$ $10^{+5} 1 . \mathrm{mol}^{-1}$.

\section{Effect of Organic Solvents}

The effect of different organic solvents on the absorbance of the coloured complex has been examined. The results obtained show that there are no colour contrast, also shift in wavelength of maximum absorption and the decrease in the intensity of the coloured complex are observed when solvents (methanol, acetic acid, formic acid, tetrahydrofuran, acetone and pyridine) are used. The effect of these organic solvent can be attributed to the decrease in the dielectric constant of the solution, and may be to the $\mathrm{pH}$ effect. (Ivanov, 1976). Therefore, water has been recommended for dilution because of high sensitivity, low cost, availability and simple handling.

\section{Study of interferences}

In order to assess the analytical applications of the proposed method, the interfering effects of foreign ions are examined by determining $20 \mu \mathrm{g}$ of $\mathrm{Pb}$ (II) in the presence of each of the interfering ions that often accompany lead in real samples to be examined latter using the recommended procedure. The results obtained are summarized in Table (7). 


\section{Table 7: Effect of diverse ions on the determination of $20 \mu \mathrm{g}$ of $\mathrm{Pb}$ (II) ion}

\begin{tabular}{|c|c|c|c|}
\hline Foreign ion & Form added & Amount added $(\mu \mathrm{g})$ & Interference* \% \\
\hline $\mathrm{Na}(\mathrm{I})$ & $\mathrm{NaNO}_{3}$ & 2000 & 1.5 \\
\hline $\mathrm{Ca}(11)$ & $\mathrm{CaCl}_{2}$ & 500 & 2.4 \\
\hline $\operatorname{Mg}(11)$ & $\mathrm{MgSO}_{4} .7 \mathrm{H}_{2} \mathrm{O}$ & 500 & 1.9 \\
\hline $\mathrm{Fe}(11)$ & $\mathrm{FeSO}_{4} .7 \mathrm{H}_{2} \mathrm{O}$ & 250 & 3.6 \\
\hline $\mathrm{Cd}(11)$ & $\mathrm{Cd}\left(\mathrm{CH}_{3} \mathrm{COO}\right)_{2} .2 \mathrm{H}_{2} \mathrm{O}$ & 100 & 1.4 \\
\hline $\operatorname{Ag}(1)$ & $\mathrm{AgNO}_{3}$ & 1000 & 3.10 \\
\hline $\mathrm{Al}(111)$ & $\mathrm{Al}\left(\mathrm{NO}_{3}\right)_{3} \cdot 9 \mathrm{H}_{2} \mathrm{O}$ & 1500 & 4.15 \\
\hline $\mathrm{Ba}(11)$ & $\mathrm{BaCl}_{2} \cdot 2 \mathrm{H}_{2} \mathrm{O}$ & 500 & 2.74 \\
\hline $\mathrm{Co}(11)$ & $\mathrm{CoCl}_{2} \cdot 6 \mathrm{H}_{2} \mathrm{O}$ & 250 & 4.9 \\
\hline $\mathrm{Cu}(11)$ & $\mathrm{CuSO}_{4} .5 \mathrm{H}_{2} \mathrm{O}$ & 500 & 3.3 \\
\hline $\mathrm{Mn}(11)$ & $\mathrm{Mn}\left(\mathrm{NO}_{3}\right)_{2} \cdot 4 \mathrm{H}_{2} \mathrm{O}$ & 500 & 2.94 \\
\hline $\mathrm{Mn}(\mathrm{Vll})$ & $\mathrm{KMnO}_{4}$ & 500 & 2.18 \\
\hline $\operatorname{As}(111)$ & $\mathrm{NaAsO}_{2}$ & 1000 & 1.89 \\
\hline $\mathrm{NH}_{4}^{+1}$ & $\mathrm{NH}_{4} \mathrm{NO}_{3}$ & 2000 & 0.8 \\
\hline $\operatorname{Th}(\mathrm{IV})$ & $\mathrm{Th}\left(\mathrm{NO}_{3}\right)_{4} \cdot 6 \mathrm{H}_{2} \mathrm{O}$ & 500 & 2.7 \\
\hline $\mathrm{U}(\mathrm{Vl})$ & $\mathrm{UO}_{2}\left(\mathrm{NO}_{3}\right)_{2} \cdot 6 \mathrm{H}_{2} \mathrm{O}$ & 1000 & 3.2 \\
\hline $\mathrm{NO}_{3}^{(-1)}$ & $\mathrm{NaNO}_{3}$ & 2000 & 1.54 \\
\hline $\mathrm{Cl}^{(-1)}$ & $\mathrm{NaCl}$ & 500 & 3.7 \\
\hline $\mathrm{SO}_{4}^{(-2)}$ & $\mathrm{Na}_{2} \mathrm{SO}_{4}$ & 500 & 4.2 \\
\hline $\mathrm{PO}_{4}{ }^{(-3)}$ & $\mathrm{NaH}_{2} \mathrm{PO}_{4}$ & 500 & 1.9 \\
\hline $\mathrm{CO}_{3}^{(-2)}$ & $\mathrm{Na}_{2} \mathrm{CO}_{3}$ & 150 & 1.1 \\
\hline $\mathrm{SO}_{3}^{(-2)}$ & $\mathrm{Na}_{2} \mathrm{SO}_{3}$ & 200 & -1.4 \\
\hline$I^{(-1)}$ & $\mathrm{NaI}$ & 200 & -1.8 \\
\hline $\mathrm{F}^{(-1)}$ & $\mathrm{NaF}$ & 500 & 0.7 \\
\hline $\mathrm{Br}^{(-1)}$ & $\mathrm{KBr}$ & 250 & 0.6 \\
\hline
\end{tabular}

*This work seems to be selective with respect to the species cited above in the Table.

\section{Comparison of Methods}

The present work proves to be simple, selective, sensitive and needs no extraction. Table (8) shows some characteristics of the spectrophotometric methods used for lead determination. These methods in general lack applications, except the dithizone method which needs extraction into organic solvent.

Table 8: Comparison of methods for $\mathrm{Pb}$ (II) determination.

\begin{tabular}{|c|c|c|c|c|}
\hline Zincon & 9.5 & 545 & $9.84 \times 10^{4}$ & Present work \\
\hline Reagent & pH & $\begin{array}{c}\lambda \max \\
(\mathbf{n m})\end{array}$ & $\begin{array}{l}\text { Molar absorptivity } \\
\text { l.mol }^{-1} \cdot \mathrm{cm}^{-1}\end{array}$ & Ref. \\
\hline Dithizone & $7-10$ & 520 & $6.8 \times 10^{4}$ & (Sandell, 1959) \\
\hline Arsenazo(111) & $4-6$ & 600 & $2.8 \times 10^{4}$ & $\begin{array}{c}\text { (Michaylovo and Kuleva, } \\
1980 \text { ) }\end{array}$ \\
\hline $\begin{array}{l}\text { 4-(2-pyridy1 } \\
\text { azorecorcinol }\end{array}$ & 10.0 & 520 & $3.7 \times 10^{4}$ & (Khopkar, 1971) \\
\hline $\begin{array}{c}\text { Pyrocatechol } \\
\text { Violet } \\
\end{array}$ & 7.6 & 645 & $5 \times 10^{4}$ & (Jarosz, 1988) \\
\hline DMHBIH & 9.0 & 430 & $1.82 \times 10^{4}$ & (Nagalakshim et al., 2011) \\
\hline BAPC & 12.5 & 440 & $1.82 \times 10^{4}$ & (Tan et al., 2010) \\
\hline (5-Br-PADAP) & 9.2 & 550 & $2.32 \times 10^{4}$ & (Pelleramo et al., 2006) \\
\hline Dithizone & $7.0-9.5$ & 520 & ------------- & (Lang et al., 2009) \\
\hline (5-Br-PADAP) & 5.5 & $(597 \& 629)$ & $3.5 \times 10^{4}$ & (Taher, 2003) \\
\hline
\end{tabular}




\section{Applications of the method}

\section{Lead in water samples}

The present method has been applied to the determination of lead in various water samples. Samples of water were collected and to each was added known amount of lead followed by extra pure $\mathrm{HNO}_{3}(5 \mathrm{ml})$, the solutions were evaporated to dryness and the volume made up to $25 \mathrm{ml}$ with distilled water (Joshi, 1985). An aliquot of each sample was then treated according to the developed procedure (this work). The results complied in Table (9) show that the method is suitable for determining lead in waters with satisfactory recovery.

\section{Table 9: Determination of lead in water samples}

\begin{tabular}{|c|c|c|c|c|c|}
\hline Sample & Ml of sample & $\begin{array}{c}\mathrm{Pb}(\mathrm{II}) \text { added } \\
(\mu \mathrm{g})\end{array}$ & $\begin{array}{l}\mathrm{Pb}(\mathrm{II}) \text { found } \\
(\mu \mathrm{g}) \text { spectr. }\end{array}$ & Recovery* \% & $\begin{array}{l}\text { Pb(II) found } \\
(\mu g) \text { A.A.S }\end{array}$ \\
\hline \multirow{9}{*}{ Tap water } & \multirow{3}{*}{1} & 5 & 5.15 & 103.0 & 5.21 \\
\hline & & 10 & 10.21 & 102.1 & 9.87 \\
\hline & & 25 & 25.15 & 100.6 & 24.96 \\
\hline & \multirow{3}{*}{3} & 5 & 4.95 & 99.0 & 5.05 \\
\hline & & 10 & 10.14 & 101.4 & 10.21 \\
\hline & & 25 & 24.87 & 99.48 & 25.06 \\
\hline & \multirow{3}{*}{5} & 5 & 4.97 & 99.4 & 4.56 \\
\hline & & 10 & 9.48 & 94.8 & 10.31 \\
\hline & & 25 & 25.54 & 102.16 & 25.87 \\
\hline \multirow{9}{*}{$\begin{array}{l}\text { Tigris river } \\
\text { water } \\
\text { (Mosul City) }\end{array}$} & \multirow{3}{*}{1} & 5 & 5.02 & 100.4 & 5.34 \\
\hline & & 10 & 9.96 & 99.6 & 9.24 \\
\hline & & 25 & 24.89 & 99.56 & 25.15 \\
\hline & \multirow{3}{*}{3} & 5 & 5.03 & 100.6 & 4.88 \\
\hline & & 10 & 10.12 & 101.2 & 9.87 \\
\hline & & 25 & 24.79 & 99.16 & 25.12 \\
\hline & \multirow{3}{*}{5} & 5 & 4.83 & 96.6 & 4.69 \\
\hline & & 10 & 10.46 & 104.6 & 10.85 \\
\hline & & 25 & 24.59 & 98.36 & 25.14 \\
\hline \multirow{3}{*}{$\begin{array}{l}\text { Ground well } \\
\text { water } \\
\text { (Mosul city) } \\
\text { (Bartela city) }\end{array}$} & 1 & 10 & 10.15 & 101.5 & 9.65 \\
\hline & 3 & 15 & 14.95 & 99.6 & 15.05 \\
\hline & 5 & 25 & 25.12 & 100.48 & 24.85 \\
\hline
\end{tabular}

(*) Average of five determinations

\section{CONCLUSION}

The development of simple, sensitive, selective and inexpensive spectrophotometric method for the determination of lead in aqueous solution has been carried out. The method is based on the reaction of lead with zincon reagent at $\mathrm{pH} 9.5$ and $\lambda$ max of $543 \mathrm{~nm}$ to form a binary 1:1 chelate which is water soluble and stable. Beer's low is obeyed over the range 0.04-1.2 $\mathrm{ppm}$ and $\varepsilon=9.84 \times 10^{4} 1 . \mathrm{mol}^{-1} \cdot \mathrm{cm}^{-1}$. The method is applied successfully to assay lead in various water samples. 


\section{REFERENCES}

Campos, M.M.A.; Tonuci, H.; Silva, S.M.; Miranda, C.E.S. (2009). Determination of lead content in medicinal plants by pre-concentration flow injection analysis. Phytochem. Analysis, 20, 445-449.

Dadfarnia, S.; Talebi, M.; Shabani, A.M.H.; Beni, Z.A. (2007). Determination of lead and cadmium in different samples by flow injection atomic absorption spectrometry incorporating a micro column. Croat. Chem. Acta, 80(1),17-23.

Dempsey, B.; Perrin, D.D. (1974). "Buffers for pH and Metal Ion Control". Champan and Hall Ltd. London, p 138

Dos Santos, W.N.L.; Dos Santos, C.M.; Costa, J.L.O.; Andrade, H.M.C.; Ferreira, S.L.C. (2004). An on-line perconcentration system for determination of cadmium in drinking water using F.A.A.S., Microchem. J., 77, 123-129.

Hargis, L.G. (1988). " Analytical Chemistry: Principles and Techniques". Prentice-Hall, Inc., New-Jersy, 424-427.

Houston, D.K.; Johnson, M.A. (1999). Blood lead level is associated with elevated blood pressure in blacks. Nutr., Rev., 57 (9 part1), 277-279.

Hung-Wei, L.; Shenh-Jen, J.; Shin-Hung, L. (1999). Determination of cadmium, mercury and lead in sea water by electrothermal vaporization isotope dilution inductively coupled plasma mass spectrometry. Spectrochim. Acta B, 549, 1367-1375.

Ivanov, V.M. (1976). Progress in and prospects for the use of heterocyclic azo compounds in analytical chemistry. Russian Chem. Rev., 45, 213-220.

Jarosz, M. (1988). Specrophotometric determination of lead with pyrocatechol violet and cationic surfactants. Microchem. J., 37,322-325.

Joshi, A.P. (1985). Rapid determination of lead by differential pulse polarography. Indian J. Chem., 24A, 1077-1078.

Khopkar, S.M. (1971). Liquid-liquid extraction of lead (II) with tributyl phosphate. Talanta, 18,833-837.

Klamtet, J.; Sangnthai, S.; Sriprag, S. (2007). Determination of lead in aqueous samples using a flow injection analysis system with on-line preconcentration and spectrophotometric detection. NU Sci. J., 4(2),122-131

Klamtet, J.; Suphrom, N.; Wanwat, C. (2008). A flow injection system for the spectrophotometric determination of lead after preconcentration by solid phase extraction on to amberlite XAD-4. Mj. Int. J. Sci. Teach., 2(02), 408-417.

Lang, L.; Konghwa, C.; Lang, Q. (2009). Spectrophotometric determination for traces of lead in various samples. Pharm. Tech., 2, 1-8.

Michaylovo, V.; Kuleva, N. (1980). Arsenazo III as a spectrophotometric reagent for determination of lead. Talanta, 27,63-66.

Nagalakshmi, B.N.; Vallina, G.V.S.; Chandrasekhar, K.B. (2011). Derivative spectrophotometric determination of lead (II) using 3,5 dimethoxy-4hydroxbenzalldehydeisonicotinoylhydrazone (DMHBIH). Int. J. Anal. Bioanal. Chem., 1(3), 82-88.

Nollet, M.L. (2000). "Hand Book of Water Analysis". Marcel Dekker, New York , 441p.

Pellerano, R.G.; Romero, C.H.; Acevedo, H.A.; Vazquez, F.A. (2006). Determination of lead in the parana river by solid phase spectroph. J. Argent. Chem. Soc. 94(4-6), 8390 . 
Rubio, C. (2005). Lead dietry intake in Spanish population (Canary Islands). J. Agric. Fd. Chem., 53(16), 6543-6549.

Sabel, C.E.; Neureuther, J.M.; Siemann, S. (2010). A spectrophotometric method for the determination of zinc,copper and cobalt ions in metallo proteins using zincon. Anal. Biochem., 397(2), 218-226.

Sandell, E.B. (1959). "Colorimetric Determination of Traces of Metals". 3rd ed. Interscience, New York, 83-84.

Taher, M.A. (2003). Derivatives spectrophotometric determination of trace lead in alloys and biological samples. Bull. Chem. Soc. Ethiop, 17(2), 129-138.

Tan, L.V.; Ngocle, N.T. (2010). Spectrophotometric determination of lead in environmental samples by benzoic acid azo phenyl calix [4] arene (BAPC). Intern. J. Chem, 2(2), 86-90.

Tewari, P.K.; Singh, A.K. (2002). Preconcentration of lead with amberlite XAD-2 and amberlite (XAD-7) based chelating resins for its determination by flame A.A.S. Talanta, 56,735-744.

Vinas, P.; Lopaz-Garcia, I.; Lanon, M. (1997). Direct determination of cadmium, zinc and lead in honey by electrothermal atomic absorption spectrometry using hydrogen peroxide as a matrix modifier. J. Agric. Fd. Chem., 45, 3952-3956.

Vogel, I.A. (1961). "A Text-Book of Quantitative Inorganic Analysis", 3rd ed., London, $443 p$.

Wilkinson, G. (1987). Editor, "Comprehensive Coordination Chemistry", Pergamon Press Ltd., Oxford ,6, 911p.

Wilson, A.T. (1966). Effects of abnormal lead content water supplies on maternity patients. Scot. Med. J., 11, 73-82 